\title{
Effects of Soil Temperatures on Spore Increase of Pasteuria penetrans Parasitizing Meloidogyne incognita in Vinyl House Conditions
}

\author{
Kazutoshi NAKASONO*, Jerome T. GASPARD** and Yasushi TATEISHI*
}

Kidney bean, sweet potato, spinach, and then sweet potato were grown in sequence in pots with soil infested with Meloidogyne incognita $(\mathrm{Mi})$ and with or without an application of Pasteuria penetrans $(P p)$ endospores under high and low soil temperature vinyl house conditions for two years to measure the effects of temperature on $P p$ and $M i$ population dynamics. At high soil temperature $P p$ endospore numbers in soil increased from an initial application of $6.6 \times 10^{4} / \mathrm{g}$ soil to 18,34 , and $127 \times 10^{4}$ after sweet potato, spinach, and sweet potato, respectively, while at low soil temperature $P p$ soil endospore numbers were 5,16 , and $12 \times 10^{4}$ in the same cropping order. Population changes of $M i$ juveniles were not significantly affected by the presence of $P p$ soil endospores at both high and low soil temperatures. A centrifugal extraction method for enumerating $P p$ soil endospore numbers is also briefly described. Jpn. J. Nematol. 23(1): 1-9 (1993).

Key words: soil temperature, cropping sequence, endospore numbers, endospore attachment, centrifugal extraction

The bacteria, Pasteuria penetrans is an obligate parasite and has been reported to have considerable potential as a biological control agent against the root-knot nematodes, Meloidogyne spp. Populations of Meloidogyne in soils infested with the parasite were extensively supressed (3, $4,5,7,8,10,11)$. The parasite, which produces endospores that attach to the cuticle of second stage juveniles $(\mathrm{J} 2)(11,12)$, acts by preventing not only reproduction by host females but also invasion of roots by juveniles $(2,4,5,13,14,16)$. More than five endospores attached per juvenile appears to be needed for preventing significant reproduction and more than 50 endospores/J2 for preventing root invasion. These numbers of endospores are reported to occur in soils containing at least $10^{5}$ spores per g soil (16).

High densities of Pasteuria endospores needed to control nematodes in a field could be attained by (1) an application of sufficient numbers of endospores produced by some mass culture system or (2) increase and establishment of high endospore densities starting from a low inoculum level in the field. Mass culture in vitro of Pasteuria has not yet been successful (1), instead, a root powder inoculum from plants heavily infected with nematodes containing Pasteuria has been proposed and used as an inoculum preparation (15).

Population increase of Pasteuria endospores in soil is influenced by various environmental factors. Endospore attachment to juveniles, development and reproduction of Pasteuria infecting

${ }^{*}$ Kyushu National Agricultural Experiment Station, Nishigoshi, Kumamoto 861-11.

** Nematech Co. Ltd., Tukuba, Ibaraki 305.

This paper was partly presented at the 21st International Nematological Symposium held in Portugal in 1992. 
Meloidogyne javanica and $M$. arenaria increased with increases in temperature between 20 and $30^{\circ} \mathrm{C}(6,13,16)$, suggesting that Pasteuria penetrans would be more useful in warm climates or under conditions where high soil temperatures prevail. Japan has a temperate climate with relatively warm summers. Soil mulching with polyethylene film and vinyl greenhouses are also commonly used, consequently soil temperatures are maintained relatively high. These conditions favor nematode development year around but may also favor Pasteuria as a biological control agent.

This study was designed to measure effects of soil temperature on population increase of Pasteuria penetrans parasitizing Meloidogyne incognita under vinyl greenhouse conditions.

\section{MATERIALS AND METHODS}

Potting soil and nematode: Meloidogyne incognita race $1 \mathrm{Mi}$ infested soil (andosol; sand 42.7 $\%$, silt, $28.1 \%$, clay $29.2 \%$ ) was collected from a sweet potato field (Kyushu National Agricultural Experiment Station, field No. 18) in April, 1990 and after thoroughly mixing the collected soil, $2.5 \mathrm{~kg}$ of soil was put in each of 36 clay pots $(20 \mathrm{~cm}$ diam.). The recommended amount of fertilizer containing $0.761 \mathrm{~g}$ urea, $3.575 \mathrm{~g}$ superphosphate, $0.500 \mathrm{~g}$ potassiumchloride, and $1.65 \mathrm{~g}$ lime was added to each pot before each cropping.

Pasteuria penetrans inoculum: Thirty day-old tomato seedlings (Lycopersicon esculentum $\mathrm{cv}$. Oogata Fukuju) planted to clay pots (20 cm diam.) containing a steam-sterilized andosol were infected with Meloidogyne incognita juveniles (J2) encumbered with Pasteuria penetrans NisHIZAWA strain $(P p)$ endospores and grown in a green house for about 50 days. Heavily galled tomato roots were removed and chopped into small pieces ( $5 \mathrm{~mm}$ in length). The chopped roots were thoroughly mixed and then a sample of the roots were homogenized in a tissue homogenizer and the number of $P p$ endospores per $g$ fresh root was counted under a compound microscope $(400 \times)$. After estimating the endospores $/ g$ fresh root weight, the roots were oven-dried at $43^{\circ} \mathrm{C}$ for three days and weighed.

Experimental design and inoculation: Eighteen pots out of 36 were randomly selected and sunk in soil within a vinyl greenhouse at six randomly selected $1 \mathrm{~m}^{2}$ areas (blocks) with three pots in each block and $50 \mathrm{~cm}$ separating each pot in a block. The soil of each block was covered with polyethylene film to acheive a high soil temperature (HST) and, likewise, the remaining 18 pots were sunk in soil within a vinyl house in a similar manner as described above but in a separate vinyl house and the blocks were mulched with a $5 \mathrm{~cm}$ layer of grass to acheive a low soil temperature (LST). The soil from 12 pots, six from each house and one from each block, were mixed thoroughly with the $P p$ root preparation described above $(5.10 \mathrm{~g}$ dried root pieces/pot, $16.5 \times 10^{7}$ spores, $6.6 \times 10^{4} / \mathrm{g}$ wet soil), the soil from 12 pots, one from each block, were mixed but no $P p$ added, and the soil from the remaining 12 pots, one pot from each block, were fumigated with $3.0 \mathrm{~m} l \mathrm{D}-\mathrm{D}$ mixture/pot ten days before planting as a control.

Cropping sequence and soil temperature: Kidney bean (Phaseolus vulgaris L. cv. Tender Green), sweet potato (Ipomoea batatas PoIRET cv. Norin No. 1), and spinach (Spinacia oleracea L. cv. Minster) were planted in sequence as shown in Table 1 . Soil temperatures at 5 and $10 \mathrm{~cm}$ depth were recorded with an automatic temperature recorder in both houses and accumulated temperatures (developmental zero $=10.0^{\circ} \mathrm{C}$ for $\mathrm{Mi}$ ) were calculated in each cropping season. Mean temperatures at 5 and $10 \mathrm{~cm}$ are shown in Table 1.

Nematode and Pasteuria spore populations: Nematodes were extracted by a modified double 
layer centrifugal technique (9) from $10 \mathrm{~g}$ soil samples taken from each pot just before budding of kidney bean and at harvest of each crop. Extracted nematodes were counted with a compound microscope $(60 \times)$. Pasteuria endospores were extracted from soil by a centrifugal extraction method at the harvests of sweet potatoes and spinach as follows: After thoroughly mixing the soil in each pot, a $5 \mathrm{~g}$ soil sample was collected from each pot and placed into $50 \mathrm{~m} l$ screw cap plastic centrifuge tubes (Corning) with $20 \mathrm{~m} l$ of tap water and shaken with an automatic lab mixer for 30 seconds. $P p$ endospores adhere to new, unused plastic centrifuge tubes, which result in a lower extraction efficiency. Plastic tubes should be washed with a detergent before use or glass screw cap centrifuge tubes should be used. After about 5 seconds of settling, $10 \mathrm{~m} l$ supernatant was withdrawn with a pipette and transferred in drops to another $50 \mathrm{~m} l$ screw cap centrifuge tube, in which $7.5 \mathrm{~m} l$ of a $60 \%$ sucrose solution ( $\mathrm{w} / \mathrm{w}$, specific gravity=1.3), $5.0 \mathrm{~m} l$ of $40 \%$ sugar solution $(\mathrm{w} / \mathrm{w}$, specific gravity $=1.2$ ) and $7.5 \mathrm{~m} l$ tap water were added to form three distinct layers with the $60 \%$ sucrose solution at the bottom and the tap water at the top. After 20 min centrifugation at 3,000 rpm in a swinging bucket type centrifuge (Kokusan SPH-108, 1,580 $\mathrm{g}$ ), the supernatant in the tube was decanted to a screw cap $50 \mathrm{~m} l$ centrifuge tube, and the tube then filled with an aliquot $(20 \mathrm{ml})$ of $99.5 \%$ ethyl alchohol and warmed in a water bath at $42^{\circ} \mathrm{C}$ for approximately 20 minutes. After thoroughly mixing, the suspension in the centrifuge tube was centrifuged again at $3,000 \mathrm{rpm}$ for $20 \mathrm{~min}$ and the top $45 \mathrm{~m} l$ of the supernatant was carefully removed with an aspirator and discarded. Forty-five $\mathrm{m} l$ of tap water was added to the tube and mixed with the remaining $5 \mathrm{~m} l$ of supernatant, after which the tubes were shaken again and centrifuged a final time at $3,000 \mathrm{rpm}$ for $20 \mathrm{~min}$. After centrifuging, the top $45 \mathrm{~m} l$ of supernatant was again carefully removed with an aspirator and the pellet at the bottom of the tube was suspended in the remaining $5 \mathrm{~m} l$ of supernatant. $P p$ endospores present were counted with a hemocytometer $(400 \times)$. Known numbers of $P p$ endospores from infected $M i$ females were suspended in distilled water and added to the $5 \mathrm{~g}$ soil samples of the control plots ( $\mathrm{D}-\mathrm{D}$ fumigated) and extracted at the same time (four replicates) in order to determine the extraction efficiency (\%) of spores. The overall extraction efficeincy of spores was about $35 \%$. The extracted soil endospore counts were adjusted by the amount of the extraction efficiency to determine the actual endospore densities. The number of spores attached per J2 was counted from 50 to 200 nematodes mounted on a slide glass in a droplet of lactophenol containing $0.001 \%$ $\mathrm{BBG}$ or aniline blue and kept at room temperature for 3 days. Nematodes prepared in this way were transparent and the stained spores could be easily counted with a compound microscope $(200 \times)$. Shoots and roots of sweet potato were weighed at harvest and the gall index of feeder roots were rated by the following grades: $0=$ no galls, $1=1$ to $10 \%$ galled, $2=11$ to $35 \%$ galled, $3=36$ to $65 \%$ galled, and $4=66$ to $100 \%$ galled.

\section{RESULTS}

Average soil temperatures during the two periods of summer cropping (kidney bean, sweet potato, and sweet potato) were approximately $30^{\circ} \mathrm{C}$ in the HST while they were approximately $26^{\circ} \mathrm{C}$ in the LST. During the winter crop (spinach) average soil temperatures were approximately $20^{\circ} \mathrm{C}$ in the HST and $13^{\circ} \mathrm{C}$ in the LST. Accordingly, accumulated degree days differed between the two houses (Table 1).

Initial J2 populations observed before budding of kidney bean were about the same among the treatments, averaging from 33 to 48 per $10 \mathrm{~g}$ dry soil. The D-D fumigated pots had only dead 
Table 1. Cropping sequence, mean soil temperature and accumulated degree days in high and low soil temperature vinyl houses during the experiment.

\begin{tabular}{|c|c|c|c|c|c|}
\hline \multirow[t]{3}{*}{ Cropping } & \multirow{3}{*}{$\begin{array}{l}\text { Time } \\
\text { (Month) }\end{array}$} & \multicolumn{4}{|c|}{ Soil temperature } \\
\hline & & \multicolumn{2}{|c|}{ High temperature ${ }^{\text {a) }}$} & \multicolumn{2}{|c|}{ Low temperature ${ }^{\text {a) }}$} \\
\hline & & Mean $\left({ }^{\circ} \mathrm{C}\right)$ & Acc. $\mathrm{DD}^{\mathrm{b})}$ & Mean $\left({ }^{\circ} \mathrm{C}\right)$ & Acc. $\mathrm{DD}^{\mathrm{b})}$ \\
\hline First: Kidney beans & Apr.-Jul. & 31.4 & 1,521 & 25.9 & 1,130 \\
\hline Second: Sweet potato & Jul.-Nov. & 27.9 & 2,068 & 25.3 & 1,783 \\
\hline Third: Spinach & Dec.-Mar. & 19.8 & 1,166 & 13.4 & 301 \\
\hline Fourth: Sweet potato & May-Oct. & 29.7 & 3,405 & 26.6 & 2,882 \\
\hline
\end{tabular}

a) Soil temperatures were recorded at $5 \mathrm{~cm}$ and $10 \mathrm{~cm}$ depth in each house and the average of both depths were calculated.

b) Acc. DD means accumulated soil temperature (degrees days, developmental zero= $10.0{ }^{\circ} \mathrm{C}$ for Meloidogyne incognita).

Table 2. Initial population density of Meloidogyne incognita juveniles in potted soil just before budding of kidney bean.

\begin{tabular}{lccccc}
\hline \multirow{2}{*}{ Treatment } & \multicolumn{4}{c}{ Number of juveniles/10 g dry soil ${ }^{\text {a) }}$} \\
\cline { 2 - 3 } & \multicolumn{2}{c}{ High soil temperature } & & Low soil temperature \\
\cline { 2 - 3 } \cline { 5 - 6 } & Live & Dead & & Live & Dead \\
\hline Pasteuria & $32.7 \pm 19.8$ & $19.6 \pm 7.9$ & & $44.3 \pm 4.3$ & $27.2 \pm 6.3$ \\
Non-Pasteuria & $47.6 \pm 24.7$ & $12.9 \pm 6.3$ & & $43.8 \pm 7.3$ & $25.5 \pm 3.4$ \\
D-D treated & 0 & $68.5 \pm 30.9$ & & 0 & $50.6 \pm 12.2$ \\
(Non-Pasteuria) & & & & & \\
\hline
\end{tabular}

a ) Mean of six replicates with $95 \%$ confidence intervals.

Table 3. Population changes of Meloidogyne incognita second stage juveniles with cropping sequence under different soil temperatures.

\begin{tabular}{lrrrrrrr}
\hline \multirow{2}{*}{ Cropping } & \multicolumn{4}{c}{ Second stage juveniles/10 g dry soil ${ }^{\text {a) }}$} \\
\cline { 2 - 3 } & \multicolumn{2}{c}{ High temperature house } & & Low temperature house \\
\cline { 2 - 3 } & Pasteuria & Non-Pasteuria & & Pasteuria & Non-Pasteuria \\
\hline 1. Kidney bean & $345 \pm 373$ & $543 \pm$ & 423 & & $1,248 \pm 980$ & $1,125 \pm 1,385$ \\
2. Sweet potato & $989 \pm 530$ & $1,414 \pm$ & 863 & & $169 \pm 83$ & $330 \pm$ & 178 \\
3. Spinach & $53 \pm 29$ & $141 \pm$ & 76 & & $37 \pm 39$ & $77 \pm$ & 43 \\
4. Sweet potato & $189 \pm 68$ & $1,107 \pm 1,386$ & & $84 \pm 85$ & $97 \pm$ & 66 \\
\hline
\end{tabular}

a) Mean of six replicates with $95 \%$ confidence intervals.

nematodes with a similar density (Table 2). During the first summer cropping of kidney bean and sweet potato, J2 numbers increased in the HST as well as in the LST but there were no significant differences between the two soil temperatures (Table 3). J2 numbers during the winter cropping (spinach) did not increase but decreased in both houses. Although $P p$ treated pots generally had smaller J2 numbers on average than non- $P p$ pots at both temperatures, no significant differences were detected.

Shoot growth and feeder root weights of sweet potato in the LST were inferior to that of the HST in each cropping season (Table 4). Average shoot and feeder root weights appeared to be suppressed more in non- $P p$ treated pots than in $P p$ treated or D-D fumigated pots (control) at both temperatures but there was a great deal of variation. Gall indices did not differ between $P p$ 
treatments or between the two soil temperatures.

Increase of $P p$ spore numbers in soil was significantly affected by soil temperatures. Spores in the HST increased by three times that of the initial inoculum level $\left(6.6 \times 10^{4}\right.$ per $\mathrm{g}$ wet soil $)$ after the first two crops of kidney bean and sweet potato in the first summer and by twenty times after the second summer sweet potato crop, while spores in the LST showed only a two-fold increase over the initial inoculum level by the end of the second summer crop (Table 5).

Both the percentage of $\mathrm{J} 2$ with spores attached and the number of spores attached per J2 were similar in the HST and LST at the harvest of sweet potato (first summer crop, Fig. 1). The number of spores attached per J2 was larger in the HST than in the LST, and the HST had a higher percentage of $\mathrm{J} 2$ with spores attached at the harvest of spinach (winter crop, Fig. 2).

Spore numbers per $g$ soil (wet) of each replicate were plotted against feeder root weights of sweet potato following spinach with the result that a positive linear relationship between the two (the tendency of heavier root weights to have produced more numbers of spores) was observed in the HST, being in contrast to no relationship in the LST (Fig. 3).

Table 4. Shoot growth, feeder root weights and root gall index of sweet potato infected with Meloidogyne incognita as affected by Pasteuria penetrans at different soil temperatures.

\begin{tabular}{|c|c|c|c|c|c|c|}
\hline \multirow[t]{2}{*}{ Treatment } & \multicolumn{3}{|c|}{ First sweet potato ${ }^{\text {b) }}$} & \multicolumn{3}{|c|}{ Second sweet potato ${ }^{\mathrm{b})}$} \\
\hline & Shoot $(g)$ & $\operatorname{Root}(\mathrm{g})$ & $\mathrm{GI}^{\mathrm{c})}$ & Shoot $(\mathrm{g})$ & $\operatorname{Root}(\mathrm{g})$ & $\mathrm{GI}^{\mathrm{c})}$ \\
\hline \multicolumn{7}{|l|}{ High temperature ${ }^{\text {a) }}$} \\
\hline Non-Pasteuria & $987 \pm 1,039$ & $20 \pm 16$ & $4.0 \pm 0$ & $1,014 \pm 500$ & $90 \pm 9$ & $3.0 \pm 0$ \\
\hline Pasteuria & $950 \pm 550$ & $24 \pm 16$ & $3.3 \pm 0.5$ & $1,664 \pm 1,613$ & $73 \pm 21$ & $2.8 \pm 0.8$ \\
\hline $\begin{array}{l}\text { D-D treated } \\
\text { (Non-Pasteuria) }\end{array}$ & $3,095 \pm 1,432$ & $49 \pm 16$ & $0.8 \pm 0.8^{\mathrm{d})}$ & $1,562 \pm 1,319$ & $74 \pm 28$ & 0 \\
\hline \multicolumn{7}{|l|}{ Low temperature ${ }^{a)}$} \\
\hline Non-Pasteuria & $60 \pm$ & $10 \pm 3$ & $3.8 \pm 0.6$ & $759 \pm$ & $16 \pm 5$ & $2.0 \pm 2.9$ \\
\hline Pasteuria & $465 \pm$ & $18 \pm 15$ & $3.2 \pm 1.0$ & $871 \pm$ & $15 \pm 10$ & $3.3 \pm 0.9$ \\
\hline $\begin{array}{l}\text { D-D treated } \\
(\text { Non-Pasteuria })\end{array}$ & $1,133 \pm$ & $40 \pm 19$ & $0.2 \pm 0.4^{\mathrm{d})}$ & $2,042 \pm$ & $97 \pm 115$ & 0 \\
\hline
\end{tabular}

a ) High and low temperature stands for high and low soil temperature vinyl house, respectively.

b ) Mean of six replicates with $95 \%$ confidence intervals. One plant of first sweet potato from nonPasteuria treatment in low soil temperature house and two of second sweet potato from nonPasteria treatment in high soil temperature house died two months after planting.

c) GI stands for gall index, graded from 0 to 4.

d) Nematode contamination occurred in some pots and those pots were again fumigated with $\mathrm{D}-\mathrm{D}$ fumigant.

Table 5. Increase in Pasteuria penetrans spores in soil infested with Meloidogyne incognita on four potted crops in sequence during two years.

\begin{tabular}{lcc}
\hline \multirow{2}{*}{ Cropping } & \multicolumn{2}{c}{ spores/g soil ${ }^{\text {a) }}$} \\
\cline { 2 - 3 } & High soil temperature & Low soil temperature \\
\hline Kidney bean & - & - \\
Sweet potato & $18.1 \pm 7.7 \times 10^{4}$ & $5.4 \pm 1.7 \times 10^{4}$ \\
Spinach & $33.6 \pm 23.0 \times 10^{4}$ & $16.0 \pm 10.8 \times 10^{4}$ \\
Sweet potato & $127.2 \pm 56.5 \times 10^{4}$ & $13.0 \pm 5.4 \times 10^{4}$ \\
\hline
\end{tabular}

a) Mean of six replicates with $95 \%$ confidence intervals. Inoculum level $=6.6 \times 10^{4} / \mathrm{g}$ soil. 


\section{DISCUSSION}

Although populations of Meloidogyne incognita juveniles were not significantly suppressed by Pasteuria penetrans at both high and low soil temperatures, increase of spore numbers during the cropping sequence was greater in the former than in the latter. The cause of this difference would be related to the following; 1) host nematode population densities, 2) amount of host plant roots, 3) greater spore production by Pasteuria penetrans at higher temperature, and 4) other environmental factors.

Nematode populations and plant root weights (sweet potato) tended to be greater at the high

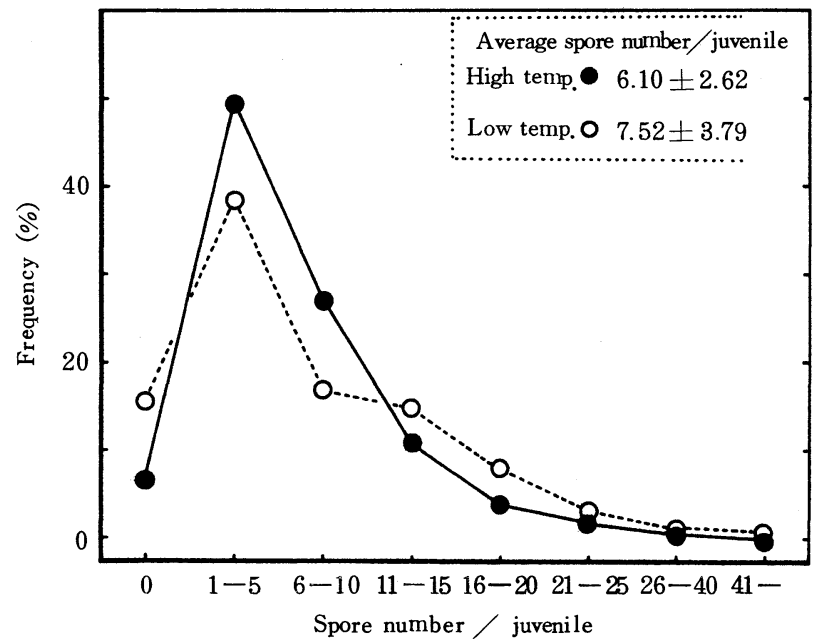

Fig. 1 Distribution frequency of Pasteuria penetrans spores per Meloidogyne incognita second stage juvenile in high and low soil temperature houses at harvest of sweet potato (first summer crop). Average spore numbers $=$ mean of $\mathrm{six}$ replicates with standard deviation.

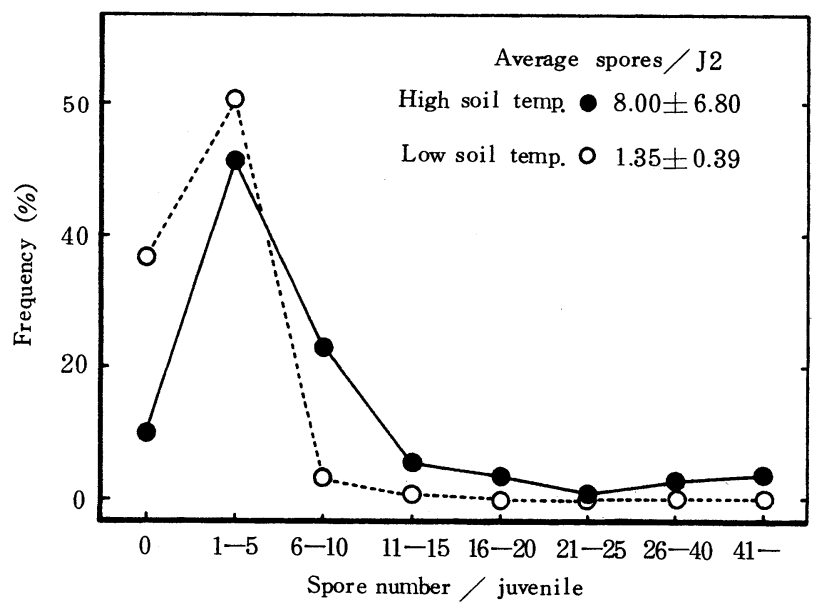

Fig. 2 Distribution frequency of Pasteuria penetrans spores per Meloidogyne incognita second stage juvenile in high and low soil temperature vinyl houses at harvest of spinach (winter crop). Average spore numbers=mean of six replicates with standard deviation. 


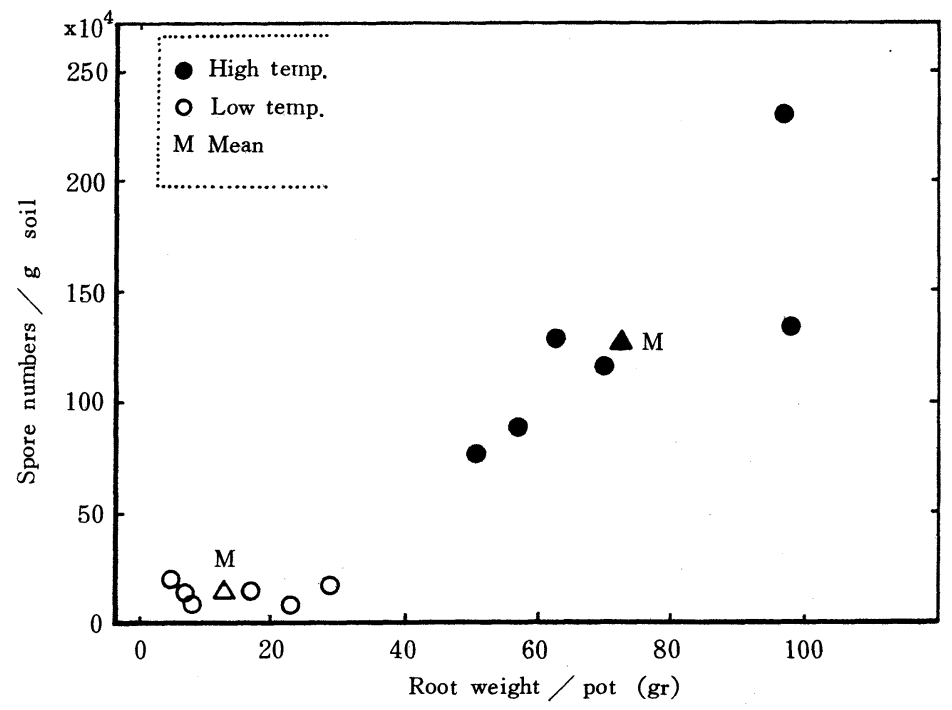

Fig. 3 Relationship between spore numbers per $g$ soil of Pasteuria penetrans and root weights of sweet potato (second summer crop).

soil temperature than at the low temperature (Tables 3 and 4). The relationship between spore numbers and plant root weights at the harvest of the second sweet potato showed a positive corelation in the high soil temperature but not at the low temperature (Fig. 3). These results suggest that high soil temperature $\left(\right.$ about $30^{\circ} \mathrm{C}$ ) stimulates both root growth of sweet potato and a proliferation of the host nematode infected with $P$. penetrans.

The number of spores attached to juveniles in the winter crop (spinach) was also higher in the high soil temperature compared to that of the low but it was about the same in the summer crop (Figs. 1 and 2). Since soil spore densities in the winter crop did not significantly differ, it is considered that movement of juveniles was more active and therefore J2 encountered more spores in soil in the high soil temperature $\left(20^{\circ} \mathrm{C}\right)$ than in the low temperature $\left(13^{\circ} \mathrm{C}\right)$, while movement of juveniles during the summer crops were not affected by the $5^{\circ} \mathrm{C}$ difference between the high and low soil temperatures. The reason of this, however, is not known here.

Cropping of plants tolerant to either Meloidogyne spp. or to high temperatures in Meloidogye infested soil would be likely to result in good reproduction of $P$. penetrans and rapid increase in endospore densities in soil. Increase of $P$. penetrans spores in soil would be also related to the survival rate of spores and it would be affected by soil temperature and some kind of bioenvironmental factors. Number of spores remaining on decaying root tissues of the host plant in soil were not estimated in the experiment here. These problems were left to be solved in the future.

\section{ACKNOWLEDGEMENTS}

We thank Tutomu Nishizawa for kindly supplying the Pasteuria penetrans used in this research. 


\section{LITERATURE CITED}

1) Bishop, A. H. \& Ella, D. J. (1991) Attempts to culture Pasteuria penetrans in vitro. Bioc. Sci. Tech. 1, 101-114.

2 ) Brown, S. M. \& SMART, G. C., Jr. (1985) Root penetration by Meloidogyne incognita juveniles with Bacillus penetrans. J. Nematol. 17, 123-126.

3 ) Brown, S. M., Kepner, J. L. \& SmarT, G. C. Jr. (1985) Increased crop yields following applicaton of Bacillus penetrans to field plots infested with Meloidogyne incognita. Soil Biol. Biochem. 17, 483486.

4 ) Davies, K. G., Kerry, B. R. \& Flynn, C. A. (1988) Observations on the pathogenicity of Pasteuria penetrans, a parasite of root-knot nematodes. Ann. appl. Biol. 112, 491-501.

5 ) Davies, K. G., LAird, V. \& KerRy, B. R. (1991) The motility, development and infection of Meloidogyne incognita encumbered with spores of the obligate hyperparasite Pasteuria penetrans. Revue Nematol. 14, 611-618.

6 ) Harz, B. \& Dickerson, D. W. (1992) Effect of temperature on attachment, development, and interaction of Pasteuria penetrans on Meloidogyne arenaria. J. Nematol. 24, 512-521.

7 ) MANKAU, R. (1980) Biological control of nematode pests by natural enemies. Ann. Rev. Phytopathol. 18, 415-440.

8 ) MankaU, R. \& PRASAD, N. (1975) Infectivity of Bacillus penetrans in plant-parasitic nematodes. J. Nematol. 9, 40-45.

9 ) Nakasono, K., Sano, Z. \& ARAKI, M. (1986) Changes in the populations of Meloidogyne incognita, Helicotylenchus spp. and free living nematodes in sweet potato field during the early growing season. Jpn. J. Nematol. 16, 56-63. (In Japanese with English summary)

10) Oostendorp, M., Dickson, D. W. \& Mitchell, D. J. (1991) Population development of Pasteuria penetrans on Meloidogyne arenaria. J. Nematol. 23, 58-64.

11) SAYre, R. M. (1980) Biocontrol: Bacillus penetrans and related parasites of nematodes. J. Nematol. 12, 260-270.

12) SAYRe, R. M. \& Wergin, W. P. (1977) Bacterial parasite of a plant nematode: morphology and ultrastructure. J. Bacteriol. 129, 1091-1101.

13) Stirling, G. R. (1981) Effect of temperature on infection of Meloidogyne javanica by Bacillus penetrans. Nematologica 27, 458-462.

14) Stirling, G. R. (1984) Biological control of Meliodogyne javanica with Bacillus penetrans. Phytopathology 74, 55-60.

15) Stirling, G. R. \& Wachtel, M. F. (1980) Mass production of Bacillus penetrans for the biological control of root-knot nematodes. Nematologica 26, 308-312.

16) Stirling, G. R., Sharma, R. D. \& Perry, J. (1990) Attachment of Pasteuria penetrans spores to the root-knot nematode Meloidogyne javanica in soil and its effects on infectivity. Nematologica 36, 246252 .

Accepted for publication: January 29, 1993 


\title{
和文摘要
}

\section{ビニルハウス条件におけるサツマイモネコブセンチュウ寄生性 Pasteuria penetrans の増殖に及ほす土壌温度の影響}

\author{
中園 和年・Jerome T. Gaspard・立石 靖
}

サツマイモネコブセンチュウ連作圃場の黒ボク土 $(2.5 \mathrm{~kg})$ を径 $20 \mathrm{~cm}$ 素焼鉢につめ、高温条件 (夏 期 $\left.30^{\circ} \mathrm{C}\right)$ または低温条件 (同 $\left.26^{\circ} \mathrm{C}\right)$ に設定したビニルハウスに埋設して (各 6 反復)、2 年間にわたり インゲンマメーサツマイモ-ホウレンソウーサツマイモを栽培し、土壌中の線虫と Pasteuria 胞子の密度 の増加・変動を調べた。供試ネコブセンチュウの密度は高温条件で高い傾向を示したが低温条件との 有意差はなかった。Pasteuria の密度は最終的に高温条件では初期接種密度 $\left(6.6 \times 10^{4} / \mathrm{g}\right.$ 土壤)の 20 倍 に増えたのに対し、低温条件ではわずか 2 倍程度に留まった。線虫の密度はP Pasteuria の存在により抑 えられる傾向であったが有意差はなかった。高温条件での Pasteuria の密度増加は「サッマイモの根の 増大一線虫の高繁殖-Pasteuriaの高繁殖」の関連により生じた可能性が推察された。土壤中に存在する 出芽細菌胞子の遠心分離法と幼虫に付着した胞子の染色検鏡法を開発し、概略記述した。 